\title{
Analisis Daerah Risiko Bencana Kebakaran di Kota Surabaya Menggunakan Sistem Informasi Geografis
}

\author{
Dinimiar Fitrah Saraswati dan Agung Budi Cahyono \\ Departemen Teknik Geomatika, Fakultas Teknik Sipil dan Perencanaan, Institut Teknologi Sepuluh \\ Nopember (ITS) \\ e-mail: agungbc@geodesy.its.ac.id
}

\begin{abstract}
Abstrak - Keterbatasan sumberdaya pemadaman menjadi salah satu kendala yang paling sering dihadapi di lapangan, sehingga kegiatan pengendalian perlu difokuskan ke wilayah-wilayah dengan risiko kebakaran yang lebih besar. Analisis dilakukan menggunakan metode skoring. Analisis spasial berupa jangkauan dan overlay pada 7 parameter yang digunakan, kemudian dilakukan skoring dan pembobotan untuk menentukan wilayah yang memiliki tingkat risiko kebakaran berskala rendah, sedang, dan tinggi. Analisis daerah risiko bencana kebakaran dilakukan berdasarkan kriteria-kriteria yang telah ditentukan mengacu pada Peraturan Menteri Pekerjaan Umum No. 20/PRT/M/2009. Dari hasil penelitian diketahui bahwa daerah dengan risiko tinggi terjadinya bencana kebakaran terdapat di 11 kecamatan pada tahun 2014 , 2 kecamatan di tahun 2015, dan 5 kecamatan di tahun 2016. Lebih dari $83 \%$ kejadian kebakaran terjadi di kawasan lahan terbangun yang termasuk dalam tingkat risiko tinggi bencana kebakaran.
\end{abstract}

Kata Kunci-Analisis Spasial, Metode Skoring, Daerah Risiko Kebakaran, SIG.

\section{PENDAHULUAN}

$\mathrm{K}$ EBAKARAN merupakan suatu ancaman bagi keselamatan manusia, harta benda maupun lingkungan. Dengan adanya perkembangan dan kemajuan pembangunan yang semakin pesat, resiko terjadinya kebakaran semakin meningkat di Kota Surabaya. Kepadatan penduduk yang meningkat, banyaknya pembangunan gedung perkantoran, kawasan perumahan, industri yang semakin berkembang sehingga menimbulkan kerawanan dan apabila terjadi kebakaran membutuhkan penanganan secara khusus.

Informasi mengenai daerah risiko kebakaran merupakan informasi yang sangat penting dan diperlukan oleh fire manager atau pengambil keputusan di dalam kegiatan pengendalian kebakaran. Keterbatasan sumberdaya pemadaman menjadi salah satu kendala yang paling sering dihadapi di lapangan. Karena itu kegiatan pengendalian perlu difokuskan ke wilayah-wilayah dengan risiko kebakaran yang lebih besar.

Peta daerah risiko kebakaran karenanya berperan penting di dalam membantu fire manager di dalam mengambil keputusan tersebut. Penyajian secara spasial akan lebih membantu memberikan gambaran yang jelas dan akurat mengenai lokasi, jarak serta aksesibilitas antara lokasi daerah risiko dengan sumber daya pemadaman yang ada di lapangan ${ }^{[1]}$. Dari penelitian ini akan dibuat peta daerah risiko kebakaran di Kota Surabaya yang diharapkan dapat digunakan sebagai acuan fire manager dalam pengambilan keputusan.

\section{METODOLOGI PENELITIAN}

\section{A. Lokasi Penelitian}

Lokasi penelitian dalam penelitian studi ini yaitu di Kota Surabaya. Secara geografis Kota Surabaya berada di $7^{\circ} 9^{\prime}$ $7^{\circ} 21^{\prime}$ LS dan $112^{\circ} 36^{\prime}-112^{\circ} 57^{\prime}$ BT.

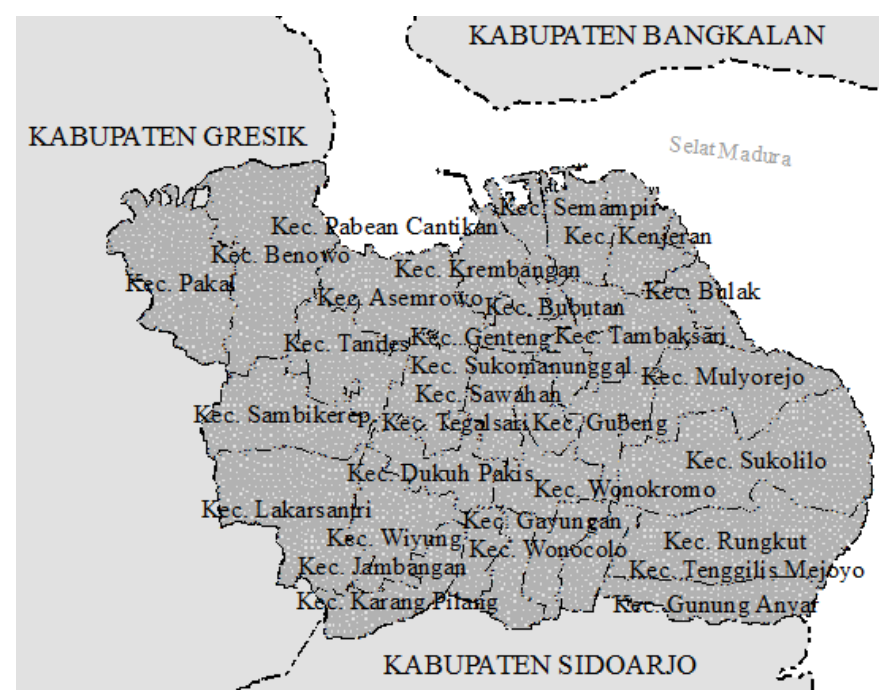

Gambar 1. Lokasi Penelitian.

(Sumber: BAPPEKO Surabaya, 2012)

\section{B. Data dan Peralatan}

1) Data

Data yang digunakan dalam penelitian ini didapat dari instansi terkait, dalam hal ini adalah Dinas Pemadam Kebakaran, Dinas Kependudukan, dan Badan Perencanaan dan Pembangungan Kota (BAPPEKO) Surabaya.

2) Peralatan

Peralatan yang digunakan pada penelitian ini meliputi:

1. Perangkat Keras

a. GPS Handheld Garmin Montana 650

b. Laptop

2. Perangkat Lunak

a. ArcGIS 10.2.2.

b. Google Maps (pencarian koordinat).

c. Global Mapper (konversi koordinat).

d. Microsoft Office (Ms. Word, Ms. Excel)

\section{Tahapan Pengolahan Data}

Tahapan pengolahan data pada penelitian ini adalah sebagai berikut:

1. Pengumpulan Data

Berikut data yang digunakan dalam penelitian ini. 
Tabel 1

Variabel dan Definisi Operasional

\begin{tabular}{|c|c|c|}
\hline No. & Variabel & Definisi Operasional \\
\hline 1. & $\begin{array}{lr}\text { Penggunaan } & \text { lahan } \\
\text { eksisting } & \text { berdasarkan } \\
\text { fungsi } & \text { kegiatan } \\
\text { bangunan } & \end{array}$ & $\begin{array}{l}\text { Angka risiko fungsi bangunan yang } \\
\text { menyebabkan bencana kebakaran dalam } \\
\text { satu wilayah. }\end{array}$ \\
\hline
\end{tabular}

2. Kepadatan penduduk Proporsi jumlah penduduk dengan luas permukiman suatu wilayah. Di kondisi eksisting, semakin padat penduduk maka semakin rentan terjadi kebakaran.

3. Kepadatan bangunan Proporsi jumlah bangunan dengan luas wilayah. Di Kota Surabaya, kepadatan bangunan yang tinggi akan memunculkan berbagai permasalahan. Salah satunya adalah kerentanan terjadinya bencana kebakaran

4. Kejadian kebakaran Frekuensi dan lokasi kejadian kebakaran pada suatu wilayah

5. Lokasi pos pemadam Radius efektivitas pelayanan pos kebakaran pemadam kebakaran dalam suatu wilayah

6. Waktu Tanggap Bencana Untuk mengurangi potensi kerusakan Kebakaran akibat bencana kebakaran, pos pemadam kebakaran yang ada harus dapat memenuhi waktu tanggap bencana kebakaran kurang dari 15 menit

7. Lokasi sumber potensi Radius efektivitas pasokan air pos air pemadam kebakaran di suatu wilayah

- Sumur tandon PMK

- Sungai

2. Pembuatan Geodatabase

Hasil dari pengumpulan data selanjutnya dilakukan pembuatan geodatabase untuk data non spasial menjadi data spasial, dan konversi ke format shapefile untuk data spasial. Kemudian dilakukan transformasi sistem koordinat menjadi WGS84 UTM Zona 49S dari semua data-data tersebut.

3. Analisis Spasial

Analisis spasial dilakukan untuk data lokasi pos pemadam kebakaran, lokasi terjadinya bencana kebakaran (terdapat pada layer waktu tanggap kebakaran), dan lokasi sumber potensi air sesuai dengan Permen PU No. 20 Tahun 2009 tentang Pedoman Teknis Manajemen Proteksi Kebakaran di Perkotaan.

a. Lokasi Pos Pemadam Kebakaran

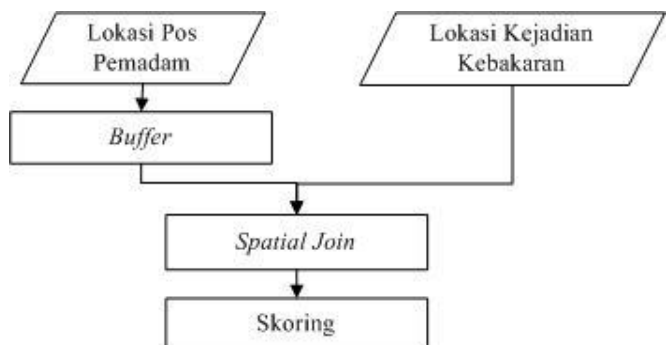

Gambar 2. Diagram Analisis Spasial Lokasi Pos Pemadam Kebakaran.

Lokasi pos pemadam kebakaran hasil plotting selanjutnya dilakukan proximity buffer sejauh 2,5 km. Hasil dari buffer tersebut kemudian dilakukan overlay spatial join terhadap lokasi terjadinya kebakaran yang terdapat pada layer waktu tanggap bencana kebakaran. b. Lokasi Sumber Potensi Air

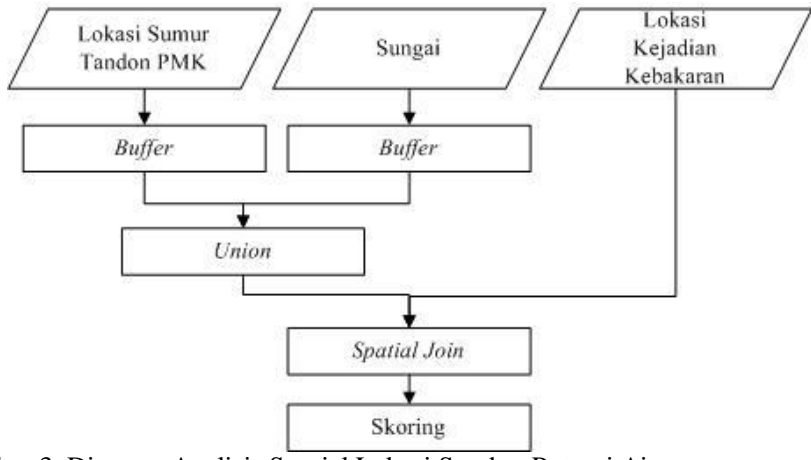

Gambar 3. Diagram Analisis Spasial Lokasi Sumber Potensi Air

Lokasi sumber potensi air terdiri dari dua data yakni sumur tandon PMK dan sungai di Kota Surabaya. Data tersebut selanjutnya dilakukan proximity buffer sejauh $61 \mathrm{~m}$ sesuai dengan Peraturan Menteri Pekerjaan Umum Nomor 20 Tahun 2009 tentang Pedoman Teknis Manajemen Proteksi Kebakaran di Perkotaan. Hasil dari buffer tersebut kemudian dilakukan penggabungan dengan overlay union. Kemudian dilakukan overlay spatial join terhadap lokasi terjadinya kebakaran yang terdapat pada layer waktu tanggap bencana kebakaran.

4. Skoring

Pemberian nilai (skoring) dilakukan sesuai dengan Peraturan Menteri Pekerjaan Umum No. 20/PRT/M/2009, dimana Angka Klasifikasi Risiko Kebakaran (ARK) memiliki rentang antara 3 (risiko tinggi) sampai dengan 7 (risiko rendah), yaitu:

- Skala klasifikasi kebakaran 3: risiko kebakaran sangat tinggi.

- Skala klasifikasi kebakaran 4: risiko kebakaran tinggi.

- Skala klasifikasi kebakaran 5: risiko kebakaran sedang.

- Skala klasifikasi kebakaran 6: risiko kebakaran rendah.

- Skala klasifikasi kebakaran 7: risiko kebakaran sangat rendah.

5. Integrasi Data

Integrasi data dilakukan untuk menggabungkan data dengan melakukan overlay union untuk data berbentuk polygon dan data overlay spatial join untuk data berbentuk titik dengan data berbentuk poligon.

6. Pembobotan

Pembobotan yang digunakan dalam penelitian sebagai berikut:

Tabel 2.

Bobot Tiap Parameter

\begin{tabular}{clc}
\hline \hline No. & \multicolumn{3}{c}{ Data yang Digunakan } & Bobot \\
\hline 1. & $\begin{array}{l}\text { Penggunaan lahan berdasarkan fungsi } \\
\text { bangunan }\end{array}$ & $15 \%$ \\
2. & Kepadatan penduduk netto tahun 2014-2016 & $5 \%$ \\
3. & Kepadatan bangunan tahun 2014-2016 & $15 \%$ \\
4. & Kejadian kebakaran di Kota Surabaya tahun 2014-2016 & $15 \%$ \\
5. & Lokasi pos pemadam kebakaran & $20 \%$ \\
6. & Waktu tanggap bencana kebakaran tahun 2014-2016 & $15 \%$ \\
7. & Lokasi sumber potensi air (sumur tandon dan sungai) & $15 \%$ \\
\hline \hline
\end{tabular}

Sumber: RISPK Pagar Alam, 2013

7. Klasifikasi 
Hasil dari pembobotan kemudian akan dilakukan klasifikasi dengan menghitung interval dari masingmasing kelas. Proses klasifikasi akan menghasilkan wilayah dengan kelas risiko tinggi, sedang, dan rendah. Berikut perhitungan untuk melakukan klasifikasi:

$N=\frac{\sum \text { BixSi }}{\text { Keseluruhan Bobot }}$

Keterangan:

$\mathrm{N}=$ Total Bobot Nilai

$\mathrm{Bi}=$ Bobot pada Tiap Kriteria

$\mathrm{Si}=$ Skor pada Tiap Kriteria

Kemudian selang tiap-tiap kelas diperoleh dari jumlah nilai maksimum dari tiap bobot dan skor dikurangi jumlah dengan jumlah nilai minimumnya yang kemudian dibagi dengan jumlah kelas dengan rumus :

$$
\begin{aligned}
& N \min =\frac{\sum\left(\text { BixSkor }_{\min }\right)}{\sum B i} \\
& N \max =\frac{\sum\left(\text { BixSkor }_{\max }\right)}{\sum B i} \\
& \text { Selang Interval }=\frac{\sum N_{\text {max }}-N_{\text {min }}}{\text { Kelas }}
\end{aligned}
$$

Hasil klasifikasi ini yang digunakan dalam penentuan kecamatan dengan risiko terjadinya bencana kebakaran di Kota Surabaya tahun 2014-2016.

8. Analisis

Dilakukan apabila terdapat perubahan zonasi daerah rawan bencana kebakaran untuk ketiga peta yang dibuat, dan menentukan faktor-faktor apa saja yang mempengaruhi.

\section{HASIL DAN ANALISIS}

\section{A. Penggunaan Lahan Berdasarkan Fungsi Kegiatan Bangunan}

Berdasarkan data dari Dinas Pemadam Kebakaran Kota Surabaya, kejadian kebakaran lebih dari $83 \%$ terjadi di kawasan lahan terbangun.

Tabel 3.

Kejadian Berdasarkan Penggunaan Lahan

\begin{tabular}{lccc}
\multicolumn{4}{c}{ Kejadian Berdasarkan Penggunaan Lahan } \\
\hline \hline \multirow{2}{*}{ Penggunaan Lahan } & \multicolumn{3}{c}{ Kejadian } \\
\cline { 2 - 4 } & $\begin{array}{c}\mathbf{2 0 1 6} \\
\text { (Kejadian) }\end{array}$ & $\begin{array}{c}\mathbf{2 0 1 5} \\
\text { (Kejadian) }\end{array}$ & $\begin{array}{c}\mathbf{2 0 1 4} \\
\text { (Kejadian) }\end{array}$ \\
\hline Boezem & 0 & 4 & 0 \\
Fasilitas Umum & 17 & 27 & 20 \\
Industri dan Pergudangan & 17 & 42 & 64 \\
Kawasan Militer & 1 & 5 & 3 \\
Perdagangan dan Jasa & 25 & 36 & 28 \\
Perkantoran & 1 & 3 & 10 \\
Permukiman & 208 & 408 & 394 \\
RTH & 17 & 37 & 35 \\
Sawah & 6 & 21 & 12 \\
Tambak & 7 & 21 & 21 \\
Tegalan & 0 & 2 & 5 \\
\hline \hline
\end{tabular}

\section{B. Kejadian Kebakaran}

Terjadi perubahan frekuensi kejadian kebakaran di tahun 2014-2016. Hal ini disebabkan musim kemarau panjang di tahun 2014 hingga tahun 2015 sehingga angka kejadian kebakaran di Kota Surabaya meningkat, sedangkan pada tahun 2016 curah hujan tinggi sehingga frekuensi terjadinya bencana kebakaran semakin berkurang. Penggunaan lahan dari lokasi terjadinya kebakaran berpengaruh terhadap tingkat risiko bencana kebakaran yang dihasilkan dari analisis spasial.

\section{Lokasi Pos Pemadam Kebakaran}

Dari hasil analisis spasial buffer sejauh 2,5 km sesuai dengan Peraturan Menteri PU No. 20 Tahun 2009, diketahui sebagai berikut.

Tabel 4.

Jangkauan Pos Pemadam Terhadap Kejadian Kebakaran

\section{Tahun Terjadinya}

\begin{tabular}{lccc} 
Keterangan & \multicolumn{3}{c}{ Tahun Terjadinya } \\
& $\begin{array}{c}\mathbf{2 0 1 4} \\
\text { (Kejadian) }\end{array}$ & $\begin{array}{c}\mathbf{2 0 1 5} \\
\text { (Kejadian) }\end{array}$ & $\begin{array}{c}\mathbf{2 0 1 6} \\
\text { (Kejadian) }\end{array}$ \\
\hline Terjangkau & 467 & 504 & 247 \\
Tidak Terjangkau & 126 & 104 & 53 \\
\hline \hline
\end{tabular}

Dari tabel tersebut diketahui bahwa terdapat lebih dari $80 \%$ lokasi kejadian kebakaran telah terjangkau daerah pelayanan pos pemadam kebakaran Kota Surabaya.

\section{Lokasi Sumber Potensi Air}

Berdasarkan Peraturan Menteri Pekerjaan Umum Nomor 20 Tahun 2009 tentang Pedoman Teknis Manajemen Proteksi Kebakaran di Perkotaan bahwa dalam rumus perhitungan kapasitas aliran maksimum air, koefisien jarak menghisap air dari sumber air ke mobil tangki ke lokasi kebakaran adalah 61 meter. Diketahui dari hasil pengolahan data lebih dari $83 \%$ lokasi terjadinya kebakaran belum tercakup dalam daerah jangkauan pasokan air. Hal ini disebabkan dalam penelitian ini hanya memanfaatkan sumber air berupa data sumur tandon PMK dan sungai yang terdapat di Kota Surabaya. Sedangkan dalam penanganan di lapangan penggunaan sumber air meliputi sumber air alam seperti kolam air, danau, sungai, jeram, sumur dalam dan saluran irigasi; maupun buatan seperti tangki air, tangki gravitasi, kolam renang, air mancur, reservoir, mobil tangki air dan hidran.

\section{E. Klasifikasi}

Dengan menggunakan rumus perhitungan interval kelas, didapatkan:

Tabel 5.

Jumlah Kecamatan dalam Kelas Risiko Bencana Kebakaran Tahun 20142016

\begin{tabular}{lccc}
\hline \hline \multirow{2}{*}{ Kelas } & \multicolumn{3}{c}{ Tahun } \\
\cline { 2 - 4 } & $\begin{array}{c}\mathbf{2 0 1 4} \\
\text { (Kecamatan) }\end{array}$ & $\begin{array}{c}\mathbf{2 0 1 5} \\
\text { (Kecamatan) }\end{array}$ & $\begin{array}{c}\mathbf{2 0 1 6} \\
\text { (Kecamatan) }\end{array}$ \\
\hline Risiko Rendah & 3 & 1 & 3 \\
Risiko Sedang & 18 & 28 & 23 \\
Risiko Tinggi & 10 & 2 & 5 \\
\hline \hline
\end{tabular}

Salah satu faktor yang mempengaruhi perubahan tersebut karena terjadinya musim kemarau panjang di tahun 20142015 sehingga angka kejadian kebakaran di Kota Surabaya meningkat dan pada tahun 2016 curah hujan tinggi sehingga frekuensi terjadinya bencana kebakaran semakin berkurang.

Di tahun 2014 kecamatan dengan risiko tinggi terjadi kebakaran mencapai 10 kecamatan dikarenakan 83,6\% bencana kebakaran yang terjadi berada di kawasan penggunaan lahan dengan kelas risiko tinggi terjadinya kebakaran. Pada tahun 2015 cenderung berkurang karena bencana kebakaran yang terjadi berada di kawasan penggunaan lahan dengan kelas risiko tinggi terjadinya kebakaran hanya 80,5\% dan di tahun 2016 mencapai 83\% (dapat dilihat pada tabel 3.1). 
Jumlah sumur tandon PMK Kota Surabaya yang semakin banyak dan waktu tanggap pemadaman kebakaran yang semakin cepat, berperan dalam berkurangnya daerah dengan tingkat risiko tinggi setiap tahunnya, dijelaskan dalam tabel berikut:

Tabel 6.

Jumlah Sumur Tandon Dan Waktu Tanggap

\begin{tabular}{|c|c|c|c|c|}
\hline \multirow{2}{*}{\multicolumn{2}{|c|}{ FAKTOR }} & \multicolumn{3}{|c|}{ TAHUN } \\
\hline & & 2014 & 2015 & 2016 \\
\hline \multicolumn{2}{|c|}{ Jumlah Sumur Tandon PMK } & 218 unit & 221 unit & 292 unit \\
\hline \multirow{2}{*}{$\begin{array}{c}\text { Waktu Tanggap } \\
\text { Pemadaman }\end{array}$} & $\leq 15$ menit & 535 kejadian & 602 kejadian & 30 kejadian \\
\hline & $>15$ menit & 54 kejadian & 6 kejadian & 0 kejadian \\
\hline
\end{tabular}

\section{F. Hasil Akhir}

Menurut BAPPEKO Surabaya, pembuatan peta daerah risiko bencana kebakaran dibuat berdasarkan tiga faktor yang terdiri dari faktor kerentanan, faktor kemampuan, dan faktor tingkat bahaya kebakaran. Peta hasil analisis masing-masing faktor kemudian dilakukan overlay untuk menghasilkan peta daerah risiko bencana kebakaran per kecamatan di Kota Surabaya tahun 2014-2016.

Tabel 7.

Peta Daerah Risiko Bencana Kebakaran di Kota Surabaya Tahun 2014-2016

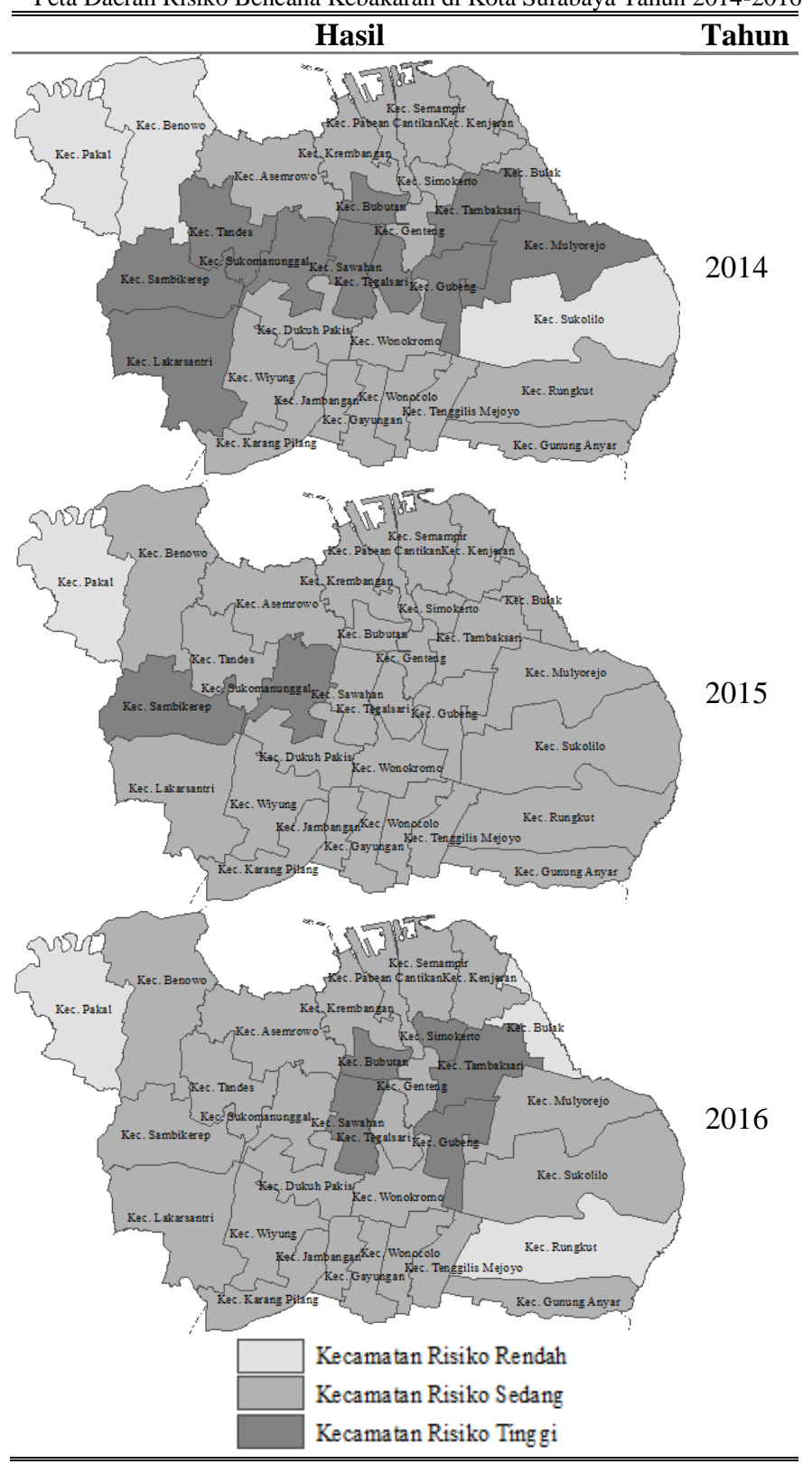

Terjadi dinamika perubahan tingkat risiko dari tahun 20142016, dapat dilihat pada tabel 3.5. Salah satu faktor yang mempengaruhi perubahan tersebut karena terjadinya musim kemarau panjang di tahun 2014-2015 sehingga angka kejadian kebakaran di Kota Surabaya meningkat dan pada terjadi curah hujan tinggi pada tahun 2016, sehingga frekuensi terjadinya bencana kebakaran semakin berkurang.

Di tahun 2014 kecamatan dengan risiko tinggi terjadi kebakaran mencapai 10 kecamatan dikarenakan 83,6\% bencana kebakaran yang terjadi berada di kawasan penggunaan lahan dengan kelas risiko tinggi terjadinya kebakaran. Pada tahun 2015 cenderung berkurang karena bencana kebakaran yang terjadi berada di kawasan penggunaan lahan dengan kelas risiko tinggi terjadinya kebakaran hanya 80,5\% dan di tahun 2016 mencapai $83 \%$.

Jumlah sumur tandon PMK Kota Surabaya yang semakin banyak dan waktu tanggap pemadaman kebakaran yang semakin cepat, maka daerah dengan tingkat risiko akan bahaya bencana kebakaran dan dampak kerugian yang diakibatkan oleh kebakaran dapat semakin berkurang.

\section{KESIMPULAN}

1. Kecamatan dengan risiko tinggi terjadinya bencana kebakaran terjadi di Kecamatan Tandes, Gubeng, Lakarsantri, Mulyorejo, Sambikerep, Sawahan, , Sukomanunggal, Tambaksari, Tegalsari, dan Kecamatan Bubutan pada tahun 2014. Pada tahun 2015 kecamatan dengan risiko tinggi hanya terjadi di Kecamatan Sambikerep dan Sukomanunggal. Kecamatan Gubeng, Sawahan, Simokerto, Tambaksari, dan Kecamatan Bubutan, termasuk ke dalam kecamatan dengan risiko tinggi kebakaran pada tahun 2016.

2. Kebakaran yang terjadi pada tahun 2014-2016 di Kota Surabaya, sebanyak lebih dari $83 \%$ kejadian terjadi di kawasan lahan terbangun yang termasuk dalam tingkat risiko tinggi terjadinya bencana kebakaran.

\section{DAFTAR PUSTAKA}

[1] Solichin dkk. 2007. Sistem Informasi Kebakaran: Pemetaan Daerah Rawan Kebakaran. Palembang: Proyek Manajemen Kebakaran Hutan.

[2] Kementerian Pekerjaan Umum. 2009. Peraturan Menteri Pekerjaan Umum No. 20 Tahun 2009 tentang Pedoman Teknis Manajemen Proteksi Kebakaran di Perkotaan. <http://pu.go.id/uploads/services/2011-12-01-13-00-08.pdf>. Dikunjungi pada 03 November 2016.

[3] Taruna, A.. 2013. Laporan Akhir Rencana Induk Sistem Proteksi Kebakaran Kota Pagar Alam. Pagar Alam: PT Ripka Rekanindo.

[4] Badan Pusat Statistik Kota Surabaya. 2016. Surabaya Dalam Angka. Surabaya: BPS Kota Surabaya.

[5] Putra, G. P.. 2011. Potensi kawasan budidaya keramba perikanan laut menggunakan Sistem Informasi Geografis (SIG) di wilayah Kepulauan Seribu, DKI Jakarta. Bogor: Institut Pertanian Bogor. 